\title{
Innovations Developed by Patients and Informal Caregivers for Needs Associated to Rheumatic Diseases
}

\author{
Maria João Jacinto ${ }^{1,2 *}$, Pedro Oliveira ${ }^{1,3,4}$ and Helena Canhão ${ }^{1,5,6,7}$ \\ ${ }^{1}$ Patient Innovation, Lisbon, Portugal, ${ }^{2}$ Católica-Lisbon School of Business and Economics, Universidade Católica \\ Portuguesa, Lisbon, Portugal, ${ }^{3}$ Copenhagen Business School, Copenhagen, Denmark, ${ }^{4}$ Nova School of Business and \\ Economics, Universidade Nova de Lisboa, Lisbon, Portugal, ${ }^{5}$ CHRC, Comprehensive Health Research Center, NOVA \\ Medical School, UNL, Lisbon, Portugal, ${ }^{6}$ EpiDoC Unit, Chronic Diseases Research Centre, Nova Medical School, \\ Universidade Nova de Lisboa, Lisbon, Portugal, ${ }^{7}$ National School of Public Health, Universidade Nova de Lisboa, \\ Lisbon, Portugal
}

Until recently, innovation in healthcare was mainly achieved through the development of new drugs, therapies, and medical devices by big pharma and medtech companies; however, the innovative potential for this field is much broader. The patients and caregivers' role in healthcare is often associated with disease management, demand for their own illness data, and its exchange with other patients. However, the patients and caregivers' capacity to innovate to cope with limitations associated with their health condition is a growing phenomenon and starting to be supported by healthcare

OPEN ACCESS

Edited by:

Sebastian C. Rodriguez-García University Hospital of La Princesa, Spain

Reviewed by:

Raul Antonio Castellanos-Moreira, Hospital Clínic de Barcelona, Spain Juan Carlos Nieto González,

Gregorio Marañón Hospital, Spain

*Correspondence:

Maria João Jacinto

maria.joao.jacinto@

patient-innovation.com

Specialty section:

This article was submitted to Rheumatology,

a section of the journal

Frontiers in Medicine

Received: 29 December 2020

Accepted: 19 February 2021

Published: 16 March 2021

Citation:

Jacinto MJ, Oliveira P and Canhão $H$ (2021) Innovations Developed by

Patients and Informal Caregivers for Needs Associated to Rheumatic Diseases. Front. Med. 8:647388. doi: 10.3389/fmed.2021.647388 stakeholders to achieve a truly patient-centric system. Our previous research has shown that these uncommon innovators can develop a wide range of solutions, from simple adaptations and products to highly technological biomedical devices. In this paper, we present novel solutions developed by rheumatic patients, their caregivers, and collaborators, published on the "Patient Innovation" platform (https://patient-innovation. $\mathrm{com} /$ ), with a focus on the innovator profile, the need that triggers the innovative process, the type of motivation behind the product, and the products developed. The most significant needs that motivate innovation are the will to increase the level of independence (71\%) and to be able to perform daily routine activities (65\%). In over $80 \%$ of cases, the fact that the market does not fully fulfill the needs felt during daily activities is the main motivation to innovate. It is thus concluded that there is room for innovation in rheumatic diseases with solutions developed by patients and informal caregivers that intend to solve needs that the healthcare market is not covering.

Keywords: patient innovation, user innovation, health, rheumatic diseases, disability

\section{INTRODUCTION}

Rheumatic diseases are in the group of diseases recognized earliest in the world (1), and although the most common rheumatic diseases present a high prevalence in the elderly population, rheumatic diseases affect people of all ages and currently have a great impact on patients' daily living as well as on society, as it is commonly reflected in high economic costs through a great consumption of healthcare and social resources.

Despite the critical importance of the healthcare sector for the economy and society, where average health spending reached $8.8 \%$ of gross domestic product (GDP) across the Organization for Economic Co-operation and Development (OECD) (2), current healthcare provision does not 
always meet patient's real and daily needs. To solve this, some patients and informal caregivers do not wait for a solution to come up in the market, and thus start developing innovative solutions to overcome limitations associated with the health condition that they face $(3,4)$. Von Hippel started to introduce the concept of user innovation as individuals or firms who expect to directly benefit from a product that they have created $(5,6)$; this concept differs from producer innovators-firms or individuals who develop novel products to benefit from selling it as a better or new product or service. Thus, when translating the concept of user innovation to the healthcare domain, patient innovators are citizens who develop useful and innovative solutions to cope with their health disorders. These patient innovations range from simple products for everyday use to unknown therapies and high-tech solutions (7). These findings suggested that patients and informal caregivers worldwide may contribute with a high number of innovative solutions with a valid need-based motivation and, if shared and adopted, can improve not only their quality of life but also the life of others with similar health conditions (8). This was the motivation for the creation of the website www.patient-innovation.com, a non-profit international, multilingual, and open platform which currently presents over 1,500 solutions developed by patients, informal caregivers, and collaborators which have been submitted or collected, medically validated, and shared.

In this paper, it is our intention to present and describe relevant innovative solutions developed by rheumatic patients, their informal caregivers, and collaborators, who decided to solve some of their everyday needs-originated by the health condition that they face-but could not find any solution in the market.

\section{METHODS}

In order to analyze innovative solutions developed by patients and informal caregivers, the 'Patient Innovation' platform (www.patient-innovation.com) was used as its presents itself as a centralized inventory of patient-developed solutions.

The 'Patient Innovation' platform provides the opportunity to patients and caregivers to actively engage in sharing solutions within the Patient Innovation community. In order to share a novel solution, the user must register on the website (the connection to Patient Innovation is always encrypted and personal data is only stored in high security data centers located in the European Union) and, once logged in, the user can write down his/her solutions for dealing with a condition in his/her daily life (information required: solution title, description, about the innovator, and optional images and videos). Before being published, the Patient Innovation's medical team evaluates and validates (or not) the submitted solutions, by only approving the ones that are not drugs, chemicals, intake/topical substances, invasive devices, or other visibly and intrinsically dangerous proposals. Once these are online, they are available to everyone who may be interested, or can benefit from the published solutions.

The medically validated and published solutions in the 'Patient Innovation' platform were screened, and solutions that showed features to be possible solutions for rheumatologic diseases were selected. In a first stage analysis, disease-based motivation was screened and rheumatology-based solutions were distinguished from solutions that cover rheumatologic patients' needs/symptoms but were based on other medical conditions. Through the innovation description and information available about the innovator, the type of innovator (patient, caregiver, or collaborator), sex, country, product category (the exact role/goal of the solution developed, divided into the following categories: activities of daily living, pain/therapy, hobbies, and movement), motivation (why the innovators had to develop a novel solution to cope with a limitation/need related with the health condition that they face, divided into the following categories: "the products in the market were not useful to satisfy the need," "there was not any alternative in the market," "cost of the alternatives in the market," and "other") and need to innovate (the need that made the patient, caregiver, or collaborator to innovate and create a novel product, divided into the following categories: "to be able to perform personal hygiene tasks," "to be able to perform a daily routine activity," "to increase the level of independency," "to be able to move," "to reduce pain," "to replace a lost function," "to improve therapy," and "other") were studied. The criteria used for categorization was developed by the authors based on the information available in the solutions description fields (solution title, description, about the innovator, optional images, and videos) posted on the 'Patient Innovation' platform.

\section{RESULTS}

The 'Patient Innovation' platform presented 1,399 medically screened and published solutions when consulted on July $8^{\text {th }}$ 2020 for the purpose of this research work. From those, 101 published innovations showed features that marked them as possible solutions for rheumatologic patients; most of those solutions were developed for activities of daily living (54\%), whereas for hobbies (24\%), pain/therapy (15\%), and movement (9\%) are other significant types of products described in the platform.

Thirty-four percent ( $n=34$, Table 1) of those solutions were developed as a response to rheumatologic-based needs by patients, informal caregivers, and collaborators who face difficulties associated with this disease category. The great majority of rheumatologic-based solutions (82\%) were developed in the same proportion by patients (those who develop solutions for themselves) and informal caregivers (those who develop solutions for loved ones and/or family); eighteen percent ( $n$ $=6$ ) of the solutions were developed by collaborators (those who develop solutions for someone out of his/her family/friends circle). Fifty-four percent $(n=19)$ of those solutions were developed by men ( $46 \%$ by women) and by citizens from countries of five continents (e.g., USA, Portugal, China, Australia, and Kenya).

When analyzing the need behind the innovation process for the rheumatologic-based solutions (Figure 1), the most significant ones rely on efforts to increase the level of independency $(71 \%)$ and to be able to perform a daily routine 
TABLE 1 | Innovative solutions to cope with rheumatic diseases limitations developed by patients, informal caregivers, and collaborators published in https:// patient-innovation.com/.

\begin{tabular}{|c|c|c|c|}
\hline Product & $\begin{array}{c}\text { Type of } \\
\text { innovator }\end{array}$ & $\begin{array}{l}\text { Country of } \\
\text { origin }\end{array}$ & $\begin{array}{c}\text { Rheumatologic } \\
\text { Disease }\end{array}$ \\
\hline $\begin{array}{l}\text { Hair dryer adaptation for stiff } \\
\text { upper limbs }{ }^{1}\end{array}$ & Patient & Portugal & Fibromyalgia \\
\hline $\begin{array}{l}\text { Home-made orthotic for foot } \\
\text { pain }^{2}\end{array}$ & & USA & Arthritis \\
\hline $\begin{array}{l}\text { Home-made pouches for } \\
\text { hot-cold therapy to reduce } \\
\text { pain }^{3}\end{array}$ & & Canada & Arthritis \\
\hline $\begin{array}{l}\text { ViEx, a string-based device to } \\
\text { reduce hand joints pain } 4\end{array}$ & & USA & $\begin{array}{l}\text { Rheumatoid } \\
\text { arthritis }\end{array}$ \\
\hline $\begin{array}{l}\text { Handmade toys to cope with } \\
\text { Arthritis }^{5}\end{array}$ & & USA & $\begin{array}{l}\text { Juvenile } \\
\text { Arthritis }\end{array}$ \\
\hline $\begin{array}{l}\text { Food cutting board and knives } \\
\text { to overcome poor hand grip } 6\end{array}$ & & New Zealand & $\begin{array}{l}\text { Rheumatoid } \\
\text { Arthritis }\end{array}$ \\
\hline $\begin{array}{l}\text { Tool to help with gardening } \\
\text { without having to bend down }\end{array}$ & & Belgium & Arthritis \\
\hline $\begin{array}{l}\text { Adapted transport container } \\
\text { for disabled people scooters }\end{array}$ & & Belgium & $\begin{array}{l}\text { Ehlers-Danlos } \\
\text { Syndrome }\end{array}$ \\
\hline $\begin{array}{l}\text { Nose-pad, a device to work in } \\
\text { a computer/tablet using nose } \\
\text { and } \operatorname{lips}^{9}\end{array}$ & & Sweden & Arthritis \\
\hline Gehrad, a walking aid device ${ }^{10}$ & & Germany & Osteoarthritis \\
\hline $\begin{array}{l}\text { Protective capes for wheelchair } \\
\text { users }^{11}\end{array}$ & & Belgium & $\begin{array}{l}\text { Ehlers-Danlos } \\
\text { Syndrome }\end{array}$ \\
\hline $\begin{array}{l}\text { Sandi Gloves, an easier way to } \\
\text { sand }^{12}\end{array}$ & & Australia & Arthritis \\
\hline $\begin{array}{l}\text { Chronically Simple, an app for } \\
\text { chronic diseases } \\
\text { management }^{13}\end{array}$ & & Canada & $\begin{array}{l}\text { Ehlers-Danlos } \\
\text { Syndrome }\end{array}$ \\
\hline Fashionable walking aids ${ }^{14}$ & & UK & Fibromyalgia \\
\hline $\begin{array}{l}\text { Adaptor for car key turning aid } \\
\text { to avoid wrist twisting motion }{ }^{15}\end{array}$ & Caregiver & USA & Arthritis \\
\hline Accessible zipper pull ${ }^{16}$ & & USA & Arthritis \\
\hline Assistive door locker ${ }^{17}$ & & USA & Arthritis \\
\hline $\begin{array}{l}\text { Blanket support to avoid } \\
\text { overweighting joints and still } \\
\text { not get cold }\end{array}$ & & Portugal & Arthritis \\
\hline $\begin{array}{l}\text { Light intensity regulator for car } \\
\text { traveling } 19\end{array}$ & & Portugal & Arthritis \\
\hline $\begin{array}{l}\text { Exoskeleton glove to enhance } \\
\text { hand movements }\end{array}$ & & Greece & Arthritis \\
\hline $\begin{array}{l}\text { Wheelchair tank to ease beach } \\
\text { and countryside visits }\end{array}$ & & UK & Arthritis \\
\hline $\begin{array}{l}\text { Egg collector to avoid having } \\
\text { to bend } \text { over }^{22}\end{array}$ & & Belgium & Myopathy \\
\hline Stair-climbing wheelchair ${ }^{23}$ & & China & Arthritis \\
\hline $\begin{array}{l}\text { Adapted clothes to enable } \\
\text { minimum body movement } \\
\text { while dressing }{ }^{24}\end{array}$ & & China & Osteoarthritis \\
\hline Stair-climbing booster ${ }^{25}$ & & China & Arthritis \\
\hline $\begin{array}{l}\text { Toothpaste squeezer for } \\
\text { people with poor grip } 26\end{array}$ & & USA & Arthritis \\
\hline $\begin{array}{l}\text { Orthorod, an adapted fishing } \\
\text { pole }^{27}\end{array}$ & & USA & Arthritis \\
\hline
\end{tabular}

(Continued)
TABLE 1 | Continued

\begin{tabular}{|c|c|c|c|}
\hline Product & $\begin{array}{l}\text { Type of } \\
\text { innovator }\end{array}$ & $\begin{array}{l}\text { Country of } \\
\text { origin }\end{array}$ & $\begin{array}{l}\text { Rheumatologic } \\
\text { Disease }\end{array}$ \\
\hline \multicolumn{2}{|l|}{$\begin{array}{l}\text { Swachchta Suvidha Brush, a } \\
\text { simple slip-on floor cleaner }{ }^{28}\end{array}$} & India & $\begin{array}{l}\text { Spondylosis, } \\
\text { Arthritis }\end{array}$ \\
\hline Book page turning device 29 & Collaborator & USA & Arthritis \\
\hline \multicolumn{2}{|l|}{$\begin{array}{l}\text { Kitchen safety handle for } \\
\text { limited hand strength and } \\
\text { flexibility }{ }^{30}\end{array}$} & Taiwan & $\begin{array}{l}\text { Rheumatoid } \\
\text { Arthritis }\end{array}$ \\
\hline \multicolumn{2}{|l|}{$\begin{array}{l}\text { Obi, a robotic device for } \\
\text { autonomous feeding }\end{array}$} & USA & Arthrogryposis \\
\hline \multicolumn{2}{|l|}{$\begin{array}{l}\text { 3D printing device to help to } \\
\text { dress }^{32}\end{array}$} & USA & $\begin{array}{l}\text { Arthrogryposis } \\
\text { Multiplex } \\
\text { Congenita }\end{array}$ \\
\hline \multicolumn{2}{|l|}{$\begin{array}{l}\text { E-Con, an all-terrain } \\
\text { wheelchair }^{33}\end{array}$} & Kenya & Arthritis \\
\hline \multicolumn{2}{|l|}{$\begin{array}{l}\text { Finger support to ease finger } \\
\text { deformities }^{34}\end{array}$} & USA & Arthritis \\
\hline \multicolumn{4}{|c|}{ 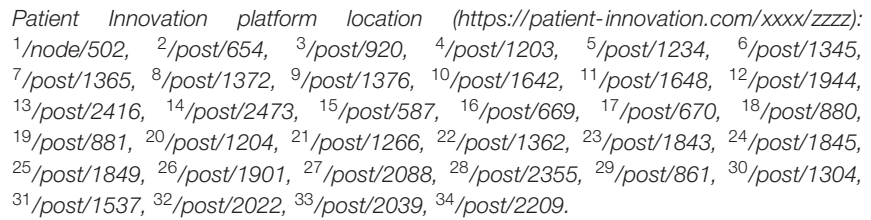 } \\
\hline
\end{tabular}

activity (65\%). Also, pain reduction (24\%), replacing a lost function $(12 \%)$, and mobility (12\%) are other relevant needs found in the innovations analyzed.

Following the World Health Organization's definition for medical device (9), $32 \%$ of the solutions developed as a response to rheumatologic-based needs under analysis are framed as Class I medical devices (10), which meets the amount of pain reduction and replace a lost function as described above; still, $68 \%$ of the analyzed solutions are not framed as medical devices. However, only $15 \%$ of these rheumatologic-based solutions are approved by regulatory authorities and are currently being commercialized.

Consequently, the type of products developed by these uncommon innovators mainly rely on activities of daily living (41\%), pain/therapy (24\%), movement (18\%), and hobbies (18\%). These innovators found as their main motivation to innovate the fact that the products in the market did not fully meet a need they had (82\%). Furthermore, the cost of alternative products (27\%) and the inexistence of useful alternatives (9\%) available in the market are also important motivations to these innovators to start developing novel solutions to cope with limitations that they face every day.

\section{DISCUSSION}

Although "innovation" is a broad term and it can be applicable in different disease's aspects, we can highlight that in the recent years "innovation" in rheumatology has widely expanded in digital health, namely through electronic health records, virtual visits, wearable technologies, and digital therapeutics which improve access, outcomes, adherence, and research $(11,12)$ or new 


\title{
Need behind the innovation process
}

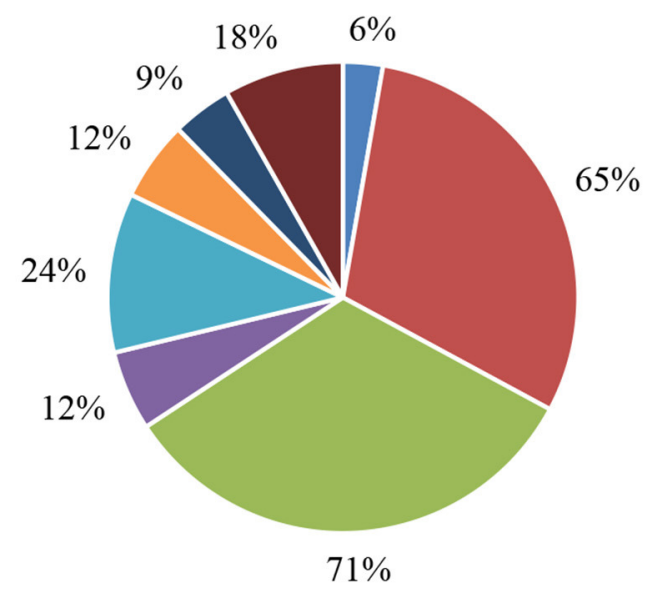

\author{
- To be able to perform personal hygiene \\ tasks \\ - To be able to perform a daily routine \\ activity \\ - To increase the level of independency \\ - To be able to move \\ - To reduce pain \\ - Replace a lost function \\ - To improve therapy
}

FIGURE 1 | Need behind the innovation process of rheumatologic-based innovators.

therapeutic production approaches such as biosimilars (13). Still, this paper intends to expose that there is still some room for innovation through solutions developed by patients and informal caregivers who intend to solve needs that the healthcare market is not yet covering. To do that, the authors have analyzed 34 rheumatologic-based solutions published on Patient Innovation's database, 14 developed by patients and 14 by informal caregivers, which reinforces that one major source of innovation are the needs that these citizens feel in their daily lives. The fact that $54 \%$ of those solutions were developed by men ( $46 \%$ by women) and by citizens from countries of five continents (e.g., USA, Portugal, China, Australia, and Kenya) reflects the patient innovation process to be as global and diverse as the medical diseases themselves. The products analyzed vary from simple devices (e.g., food cutting board and knives to overcome poor hand grip) to high-tech solutions (e.g., exoskeleton glove to enhance hand movements).

Thirty-two percent of the solutions developed under analysis are framed as Class I medical devices; however, only 15\% are approved by regulatory authorities and are currently being commercialized, as most of the solutions here described were developed to solve a daily life need felt by patients and informal caregivers and were not manufactured on a large scale for commercialization (at least at the analysis moment). This is a common approach for patient innovators, as this kind of uncommon inventors have only developed their novel solutions because they have a validated need that motivated them to innovate, and thus their main goal was to fulfill that need, not to profit from it. Still, there has been an increasing number of patients and informal caregivers who have been establishing their own solutions in the market as an effective way to distribute their solutions to others with similar needs $(14,15)$.

The authors would like to highlight the potential of platforms such as 'Patient Innovation' and other information and communication technologies to promote an easy interaction between common citizens and healthcare professionals. Mainly, healthcare professionals and other stakeholders can use these resources to learn more about patients' real needs and the solutions that they have developed to cope with them, as well as to start including patients as consultants and their innovation process into the producer innovation processes. As innovation by patients and caregivers is still a new topic that has only started to be explored in recent years, it is important that healthcare industry representatives increase their awareness of this phenomenon and support this innovation process to achieve a more effective and cheaper product development process.

Although this work only shows a brief sample of novel solutions developed by common citizens for needs associated with rheumatic diseases, as the authors are sure that many more solutions exist developed by these uncommon inventors than the ones published in 'Patient Innovation' platform, it is thus concluded that solutions developed by patients and informal caregivers can significantly contribute to rheumatic diseases innovations as it aims to solve needs that the healthcare market is not yet covering.

\section{DATA AVAILABILITY STATEMENT}

The datasets presented in this study can be found in online repositories. The names of the repository/repositories and accession number(s) can be found below: https://patientinnovation.com/.

\section{AUTHOR CONTRIBUTIONS}

MJ was responsible for conceptualization, information extraction, formal analysis, methodology, writing, and edition. $\mathrm{PO}$ and $\mathrm{HC}$ were responsible for funding acquisition, project administration, resources, supervision, validation, writing, review, and editing. All authors contributed to the article and approved the submitted version. 


\section{FUNDING}

The authors are grateful for the funding provided by the Fundação para a Ciência e Tecnologia (FCT)

\section{REFERENCES}

1. Sangha O. Epidemiology of rheumatic diseases. Rheumatology (Oxford). (2000) 39(Suppl 2):3-12. doi: 10.1093/rheumatology/39.suppl_2.3

2. Development OfEC-oa. OECD Health Statistics. (2020). Available online at: http://www.oecd.org/els/health-systems/health-data.htm2020

3. Oliveira P, Zejnilovic L, Canhão H, von Hippel E. Innovation by patients with rare diseases and chronic needs. Orphanet J Rare Dis. (2015) 10:41. doi: 10.1186/s13023-015-0257-2

4. Zejnilovic L, Oliveira P, Canhão H. Innovations by and for the patients: and how can we integrate them into the future health care system. In: Albach H, Meffert H, Pinkwart A, Reichwald R, von Eiff W, editors. Boundaryless Hospital: Rethink and Redefine Health Care Management. Berlin: SpringerVerlag (2016). p. 341-57.

5. von Hippel E. The dominant role of users in the scientific instrument innovation process. Res Policy. (1976) 5:21239. doi: 10.1016/0048-7333(76)90028-7

6. Von Hippel E. Lead Users: a source of novel product concepts. Manag Sci. (1986) 32:791-805. doi: 10.1287/mnsc.32.7.791

7. Oliveira P, Canhão H. Users as service innovators: evidence from banking to healthcare. In: Lakhani K, Harhoff D, editors. Revolutionizing Innovation. Cambridge, MA: MIT Press (2014). 32 p.

8. Oliveira P, Zejnilovic L, Azevedo S, Rodrigues AM, Canhão H. Peer adoption and development of health innovations by patients: National Representative Study of 6204 Citizens. J Med Internet Res. (2019) 21:e11726. doi: 10.2196/ 11726

9. Organization WH. Medical Device - Full Definition. Available online at: https://www.who.int/medical_devices/full_deffinition/en/

10. Strålin M. Classification of Medical Devices and Their Routes to CE Marking. CE Check Support (2020). Available online at: https://support.ce-check.eu/

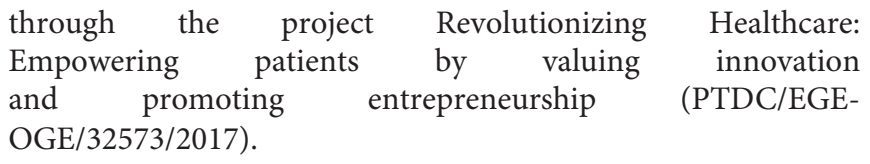

hc/en-us/articles/360008712879-Classification-Of-Medical-Devices-AndTheir-Routes-To-CE-Marking

11. Solomon DH, Rudin RS. Digital health technologies: opportunities and challenges in rheumatology. Nat Rev Rheumatol. (2020) 16:525-35. doi: 10.1038/s41584-020-0461-x

12. Rodrigues, Canhão. Innovation and digital transformation to support clinical care and prevent osteoporosis related fractures. Acta Reumatol Port. (2019) 44:171-2. Available online at: http://actareumatologica.pt/article_ download.php?id $=1408$

13. Dörner T, Strand V, Cornes P, Gonçalves J, Gulácsi L, Kay J, et al. The changing landscape of biosimilars in rheumatology. Ann Rheum Dis. (2016) 75:974-82. doi: 10.1136/annrheumdis-2016-209166

14. Shcherbatiuk V. Users as Developers and Entrepreneurs of Medical Treatments/Devices: The Case of Patients and their Families and Friends. Catholic University of Portugal (2012).

15. Habicht H, Oliveira P, Shcherbatiuk V. User innovators: when patients set out to help themselves and end up helping many. Die Unternehmung. (2013) 66:277-94. doi: 10.5771/0042-059X-2012-3-277

Conflict of Interest: The authors declare that the research was conducted in the absence of any commercial or financial relationships that could be construed as a potential conflict of interest.

Copyright (๑) 2021 Jacinto, Oliveira and Canhão. This is an open-access article distributed under the terms of the Creative Commons Attribution License (CC BY). The use, distribution or reproduction in other forums is permitted, provided the original author(s) and the copyright owner(s) are credited and that the original publication in this journal is cited, in accordance with accepted academic practice. No use, distribution or reproduction is permitted which does not comply with these terms. 